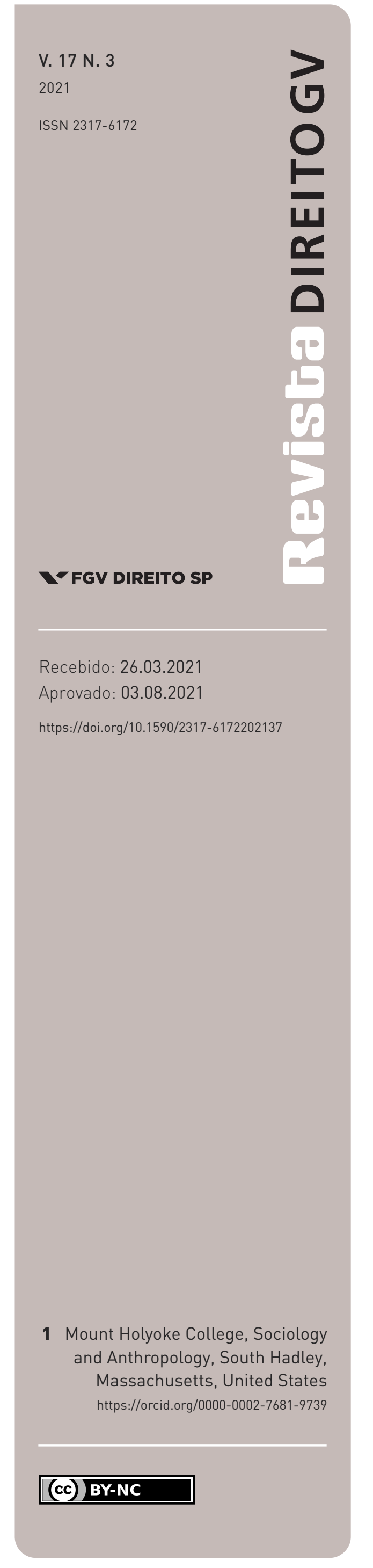

\title{
Costa Rica's Oversized Role in Latin American Sexual and Reproductive Rights Lawfare
}

O VASTO PAPEL DA COSTA RICA NA DISPUTA DOS DIREITOS SEXUAIS E REPRODUTIVOS POR MEIO DO LAWFARE NA AMÉRICA LATINA

Lynn M. Morgan ${ }^{1}$

\section{Abstract}

Costa Rica's reputation as a stable democracy and champion of inter-American human rights law makes it both beacon and bellwether for sexual and reproductive rights in the American continent. The Costa Rican government brought cases involving in vitro fertilization and same-sex marriage to the Inter-American Court of Human Rights, which issued historic decisions expanding reproductive and sexual rights across Latin America. In response, a transnational coalition of self-proclaimed prolife and pro-family organizations has targeted the Organization of American States and its system of inter-American human rights law, calling on the OAS to respect national sovereignty concerning life and family matters. This chapter traces Costa Rica's key role in Latin American sexual and reproductive rights lawfare as well as the resulting backlash.

\section{Keywords}

Costa Rica; Inter-American Court of Human Rights; Organization of American States; in vitro fertilization; anti-abortion lawfare.

\section{Resumo}

A reputação da Costa Rica como uma democracia estável e defensora da atuação da Corte Interamericana de Direitos Humanos torna o país uma referência no tema dos direitos sexuais e reprodutivos no continente americano. O governo da Costa Rica levou casos que envolviam fertilização in vitro e casamento de pessoas do mesmo sexo para discussão na Corte Interamericana de Direitos Humanos, a qual emitiu decisões históricas, ampliando os direitos reprodutivos e sexuais para toda a América Latina. Em resposta, uma organização autoproclamada pró-vida e pró-família colocou a Organização dos Estados Americanos (OEA) e o seu sistema interamericano de direitos humanos como alvo de ataque, pedindo que a OEA respeite a soberania nacional em matérias sobre família e vida. Este artigo apresenta o papel da Costa Rica na disputa dos direitos sexuais e reprodutivos por meio do lawfare na América Latina e seus resultados reativos.

\section{Palavras-chave}

Costa Rica; Corte Interamericana de Direitos Humanos; Organização dos Estados Americanos; fertilização in vitro; lawfare antiaborto. 


\section{INTRODUCTION}

Costa Rica, a small Central American country of just five million people, has played an oversized role in Latin American sexual and reproductive rights lawfare. While national-level case studies sometimes fail to capture the global social movements of which they form a part (CORRÊA and PARKER, 2020, p. 9), I argue here that Costa Rica's reputation as an exemplary democracy and distinguished champion of inter-American human rights law makes it both beacon and bellwether for sexual and reproductive rights throughout the continent. Landmark rulings issued by the Inter-American Court of Human Rights (hereafter InterAmerican Court) have stemmed from cases brought by Costa Rica, and the backlash against those decisions provides insight into the transnational strategies being deployed by "pro-life and pro-family" social movements.

The following analysis stems from the conviction that "all sex is politics" (PECHENY, FIGARI and JONES, 2008), and that sexual and reproductive rights are interrelated. While we distinguish theoretically and politically between sexual rights and reproductive rights, religious conservatives address both in their efforts to control sexual and reproductive bodies. Disciplining bodies is central to their efforts to police and defend a patriarchal, heteronormative social order based on natural law. Sexual and reproductive bodies are likewise central to conservatives' efforts to consolidate political power, as evidenced by anti-democratic, Christian nationalist movements in Brazil, Hungary, Poland, the United States, and elsewhere. Religious conservatives who target "gender ideology," sexual diversity, and reproductive autonomy often choose their topics interchangeably, substituting one hot-button issue for another. In conservative politics, debates over abortion, gender identity, same-sex marriage, and sexual education are essentially the same struggle, irrespective of attempts by activists and scholars to separate "sexual" from "reproductive" rights. This chapter focuses closely on a reproductive rights case, but my secondary analysis of the same-sex marriage ruling is no less vital to understanding Costa Rica's pivotal role in sexual and reproductive rights lawfare.

The most consequential reproductive rights case issued by the Inter-American Court in recent years is a 2012 ruling formally known as Artavia Murillo et al. ("InVitro Fertilization") v. Costa Rica. Its primary effect was to overturn Costa Rica's twelve-year ban on the practice of in vitro fertilization (IVF), but it had far-reaching implications. The judges took the opportunity to clarify that under inter-American law reproductive rights are human rights, embryos cannot be considered juridical persons, and the rights of embryos may not take precedence over those of women. In a second important ruling, the Inter-American Court responded to a request from the Costa Rican government with a 2018 advisory opinion stating that all members of the Organization of American States (OAS) must offer existing legal protections - including marriage, adoption, and inheritance rights - to same-sex couples and that transgender persons should have the right to change their names. The opinion effectively legalized same-sex marriage throughout the Americas. Like all Inter-American 
Court rulings, these advisory opinions are considered legally binding on the twenty-three countries of the continent that have signed the American Convention on Human Rights. A third matter, concerning Costa Rica's obligation to provide therapeutic abortion to women in certain circumstances, was considered by the Inter-American Court and finally resolved by the president's signature in December 2019.

In response to these decisions, a coalition of self-proclaimed pro-life and pro-family activists has attacked the OAS and its associated human rights bodies - the Inter-American Commission on Human Rights and the Inter-American Court of Human Rights - calling for national sovereignty in matters of sexual and reproductive rights (CARIBONI, 2019). ${ }^{1}$ Many of these groups subscribe, implicitly or explicitly, to the tenets of natural law, a Catholic religious principle which holds that unalienable God-given rights are fundamentally "the basis for legitimate human or positive law" (BECKWITH, 2019, p. 155). They share the biblical notion that the sole purpose of human sexuality is procreation within the context of a heteronormative marriage. This conviction provides them with a shared purpose: to oppose any policies or actions that would expand access to abortion (including therapeutic abortion), assisted reproductive technologies (such as IVF), contraception (especially emergency contraception), sterilization, or same-sex marriage. The coalition's membership comprises an assortment of conservative nongovernmental organizations, thinktanks, and legal foundations, as well as the right-wing administrations and pro-life legislative contingents from a shifting constellation of countries. To offer just a few examples: in late 2018, nine US senators urged Secretary of State Mike Pompeo to cut funding to the Inter-American Commission on Human Rights because it lobbies "for abortion in Latin America in direct contravention of U.S. law" (LANKFORD, TILLIS and ENZI, 2018; see also SABATINI, 2019). In 2019, five Latin American governments with histories of statesponsored violence (Argentina, Brazil, Chile, Colombia, and Paraguay) sent a statement to the OAS calling for the inter-American human rights system to respect states' sovereignty "to decide the most appropriate way of ensuring rights" (CANCILLERÍA DE CHILE, 2019; see also CONTESSE, 2019, p. 376; FRANCE, 2019, p. 24). A few months later, in July 2019, Pompeo announced the formation of a new Commission on Unalienable Rights, headed by a noted architect of the Vatican's pro-life strategy, Harvard law professor Mary Ann Glendon. The commission's report, issued in July 2020, prioritizes an originalist interpretation of human rights documents, ignoring subsequent developments in international human rights law.

1 National sovereignty has been a running theme in inter-American human rights accords since at least the 1930s, when the "United States was usually the most vocal proponent of this argument" (MARINO, 2019, p. 106). 
Costa Rica's reputation as a Latin American leader in the defense of international human rights and democracy gives it particular salience in sexual and reproductive rights lawfare. Costa Rica has been involved in two reproductive rights cases with continental repercussions. The first is the IVF case mentioned above; the second is a technical protocol outlining the circumstances under which therapeutic abortion may be legally performed. The Costa Rican government promised this protocol to the Inter-American Court to avoid being charged with another reproduction-related human rights violation, but the protocol was stalled for several years by domestic legislative opposition and foot-dragging. The regulation of therapeutic abortion is vitally important across the continent because it provides legal means for terminating pregnancy in cases of fatal fetal abnormalities or where a pregnancy threatens a woman's life. The issue of therapeutic abortion reveals the differences between those who would depenalize and even legalize the procedure, and those who prefer to retain criminal penalties for induced abortion (see VAGGIONE, 2018, p. 327; GONZÁLEZ VÉLEZ, MELO ARÉVALO and MARTÍNEZ LONDOÑO, 2019). Before delving into the cases, we must examine Costa Rica's pivotal role within the inter-American human rights system.

\section{Costa Rica And the InTer-A merican Human Rights System}

The Inter-American human rights system, in place for over fifty years, is composed of the Inter-American Commission on Human Rights, a quasi-judicial body that issues recommendations for member states of the OAS and submits cases before the Inter-American Court, and the Inter-American Court of Human Rights, an international tribunal with compulsory jurisdiction over member states that have ratified the American Convention on Human Rights. Established amid the pressures of the Cold War, the system has contributed to the restoration of democracy and the promotion of justice in the region. For decades it has dealt with the consequences of massive and gross human rights violations. Along with cases related to political persecution, torture, and other egregious human rights violations stemming from authoritarian regimes, the system must deal with petitions against functioning democracies, as most of the states today in the region have left behind authoritarian and dictatorial regimes (CONTESSE, 2016, p. 123).

Since the inception of the inter-American human rights system, Costa Rica has staked its national identity on supporting it (MURILLO, 2018). When the OAS set up its human rights oversight bodies in the 1960s and 1970s, during a time of serious state-sponsored human rights abuses throughout the Americas, one of its major champions was Rodolfo E. Piza Escalante (1930-2002), a Costa Rican magistrate who supported the American Convention and became the first president of the Inter-American Court. Piza, as much as any other judge in Costa Rican history, embodied Costa Rica's commitment to human rights "as a national value" (BRYSK, 2005, p. 460). Further, the first female judge on the Inter-American Court, Sonia Picado, was Costa Rican, as is the current president of the Inter-American 
Court, Elizabeth Odio Benito. In the words of political scientist Alison Brysk, "Costa Rica was the first country to ratify the [American Convention on Human Rights] and the first to accept the jurisdiction of the Inter-American Commission on Human Rights and the subsequent Inter-American Court of Human Rights" (BRYSK, 2005, p. 229). The OAS decided to locate the Inter-American Court's headquarters in San José in part to honor Piza's contributions. Costa Rica's relationship with the inter-American human rights system is the source of considerable national pride. It was significant, then, that Piza was serving as chief magistrate on Costa Rica's constitutional court (known as the Sala IV) in 2000, when he penned the decision to ban IVF.

\section{I.The BAN ON INVitro Fertilization}

Costa Rica was an unlikely setting for a struggle over IVF. The country routinely garners top rankings on international indicators, including human rights, global peace, gender equality, human development, and happiness. It boasts a world-renowned nationalized health system and high levels of literacy, and in 2010 it elected its first female president, Laura Chinchilla Miranda. The fertility rate stands at 1.7 births per woman (down from 6.7 in 1960); infant and child mortality rates have fallen to historic lows; and approximately $75 \%$ of women use modern contraception (WORLD BANK, 2020). In the 1990s, international observers had every reason to believe that Costa Rica would be a Latin American leader in advancing reproductive and sexual rights.

By the turn of the millennium, however, trouble was brewing. The previous two decades had witnessed increasing corruption and influence-peddling, rising debt and crime, cutbacks in social services, and a disintegration of the traditional two-party system. Progress toward women's rights was affected by the interference of powerful conservative forces (CEPAL, 2015, p. 63). Small, evangelical political parties were on the rise and found common cause with the Catholic hierarchy in their pro-life, pro-family, anti-abortion platforms (FUENTES BELGRAVE, 2019). Their opposition to IVF became their main rallying cry.

IVF had been briefly legal in Costa Rica from 1995 to 2000, but in 2000 a challenge was brought by an advisor to the Roman Catholic Episcopal Conference of Bishops, Hermes Navarro del Valle, who argued that the procedure violated embryos' constitutionally protected right to life. The bishops opposed IVF because the Catholic Church disapproves of "artificial" reproduction and because IVF requires men to engage in the sin of masturbation and therefore circumvents the mandate for procreative conjugal intimacy. Navarro argued that because human life begins at fertilization, any elimination or destruction of leftover or unviable embryos (a frequent practice in IVF) violates their constitutional right to life. To discard embryos, he said, is to treat them "like garbage," and to select certain embryos for implantation while rejecting others is to play Russian roulette with their lives. He also said that IVF is a commercial enterprise that trafficks in human lives (INTER-AMERICAN COURT OF HUMAN RIGHTS, 2012, p. 24; see also NAVARRO DEL VALLE, 2001). 
The Sala IV agreed. Piza based his opinion on his reading of the Costa Rican Constitution, which states that human life is inviolable, as well as on article 4.1 of the American Convention on Human Rights, which many pro-life and pro-family activists consider "the most prolife treaty in the world" (PRIESTS FOR LIFE, 2020). Article 4.1 states, "Every person has the right to have his life respected. This right shall be protected by law and, in general, from the moment of conception. No one shall be arbitrarily deprived of his life." That Piza, a former president of the Inter-American Court, would use article 4.1 to extend human rights to "unborn persons" was a monumental victory within the world of international prolife activism. It buoyed pro-life activists in other regions who hoped to extend human rights protections to embryos and fetuses (KUKLA, 2012). The renowned Argentine pro-life theorist and attorney, Jorge Scala, had this to say:

The Republic of Costa Rica not only has the honor of sheltering the Inter-American Court of Human Rights, but an even greater glory: the activities of judge Dr. Rodolfo E. Piza Escalante, who in his long years as a judge, with his wise and prudent judgments, made headway in the practice of the law of human rights. His majority opinion is emblematic, in the judgment of the Constitutional Chamber of the Supreme Court of Costa Rica, 15 March 2000, in which he protects the right to life of unborn persons that had been severely violated by the lethal technique of in vitro fertilization. It is fitting to pay homage $[\ldots]$ to the Costa Rican who raised the flag of human rights still higher for all humans, including those as yet unborn. (SCALA, 2011)

Costa Rican feminists were startled by the decision to ban IVF. Frankly, IVF did not figure among their priorities. One activist explained to me that the discourse around reproductive and sexual rights was still evolving in the late 1990s, and feminists dismissed IVF as a procedure that transformed wealthy women's infertile bodies into reproductive, gender-normative mothers (ARGUEDAS RAMÍREZ, 2014, p. 167; LUNA and WOLF, 2014, p. 7). At the time, she said, feminists were more interested in disrupting the "motherhood mandate" than helping infertile women become parents. They simply did not consider IVF a reproductive rights issue.

The IVF prohibition dramatically heightened the subjectivity of a new class of rights claimants: human embryos. The Sala IV ruled that IVF produces embryos that face a disproportionate risk of death if not implanted into a woman's uterus, whereas, in the court's words, "Our system, as inscribed in article 21 of the Constitution, states that 'human life is inviolable'" (SALA CONSTITUCIONAL, 2000; see also MORGAN, 2019). To justify their decision to grant personhood rights to embryos, the judges cited the Costa Rican Constitution, the American Convention on Human Rights, and article 31 of the Civil Code, which states that unborn persons shall be treated favorably from 300 days before birth (ACOSTA GAMBOA, 2013, p. 142; ZAMORA CASTELLANOS, 2013, 
p. 143). ${ }^{2}$ The Holy See approved of the ruling, issuing a statement in 2002 that Catholics have a "'grave and clear obligation' to oppose any law that might tolerate abortion, IVF, or embryo experimentation" (ROBERTSON, 2010, p. 66).

Several infertile women and couples affected by the ban filed a complaint with the Inter-American Commission on Human Rights in 2001, alleging violations of their rights to equality, to honor, and dignity, and to form a family under the American Convention. The Inter-American Commission on Human Rights had started to use its supranational authority to hear sexual and reproductive rights cases, rendering decisions that held governments accountable for violations and that embedded reproductive rights within the rights to health, equity, nondiscrimination, privacy, and family life. But the process was slow; the commission took nine years to issue its decision. In 2010, it agreed with the petitioners that Costa Rica's ban on IVF constituted a violation of human rights guaranteed under the American Convention, specifically the right to found a family, the right to equality and nondiscrimination, and the right to have one's private and family life respected. In response, the government mounted several half-hearted efforts to legalize IVF, all of which were so poorly drafted that they seemed designed to fail. In July 2011, the commission took the serious step of sending the case to the Inter-American Court for review; this time, the decision would be final.

The delay between 2001, when the case was originally filed, and 2011 gave anti-IVF activists plenty of time to organize. The Episcopal Conference led the way, assisted by a host of others: lay Catholic activists; academics who specialized in biology, bioethics, and bio-law (bioderecho); elite allies in government and the media; evangelical Protestant parishioners; and international nongovernmental organizations, including Virginia-based Human Life International (see KUKLA, 2012; ARGUEDAS and MORGAN, 2017). Members of the transnational pro-life movement - ADF International (formerly the Alliance Defense Fund), together with the Center for Legal Studies at C-Fam and Americans United for Life - filed amicus curiae briefs with the Inter-American Court of Human Rights, arguing that Costa Rica's ban on IVF “does not violate the American Convention on Human Rights" (ALLIANCE DEFENSE FUND, 2012a, p. 2). ${ }^{3}$ Opponents of IVF stressed the following arguments: religious values are patriotic because Catholicism is the state religion, Costa Rican law respects unborn life, national sovereignty is at stake, and powerful outside agitators were pressuring Costa Ricans to relinquish their bedrock Christian values. A growing bloc of evangelical legislators joined with the Catholic hierarchy to prevent IVF bills from coming to a vote in the legislature (ARAYA, 2015).

2 A human pregnancy lasts on average 280 days.

3 For a full list of amicus curiae filed in the case, see Rivera Juaristi (2014). 
In 2011, the anti-IVF camp mounted a sophisticated public relations effort in the media, the halls of congress, and on the streets. Movement leaders invited international pro-life activists to convene in San José for the V Pro-Life World Congress. A Catholic radio station released an announcement in which a young child was heard to say, "Hello, I'm Sofi, the third of three children, and although my parents love me from the bottom of their hearts, I know that for me to be born seven of my brothers and sisters died in the laboratory." The spot was withdrawn after complaints from listeners who worried that it would fuel discrimination against Costa Rican children who had been conceived through IVF outside the country; one of them - whose story had been publicized in a newspaper - was named Sofi (DÍAZ, 2011). The battle to influence congressional representatives got ugly; in 2013 and 2014, the Costa Rican Association for Life and Human Rights arranged for enormous anti-abortion photographs to be displayed in the halls of the Legislative Assembly (and on Facebook), in conjunction with the International Day of the Unborn on March 25. The words "Pura vida?" in dripping red paint were superimposed atop photos of bloody dismembered fetuses. ${ }^{4}$ On multiple occasions, Catholic and Protestant clerics organized massive public demonstrations of the faithful who paraded through the streets dressed in white.

Christmas tamale preparations were well underway in late 2012 when the news hit the airwaves: the Inter-American Court condemned Costa Rica for its ban on IVF. Further action from the executive branch remained stalled, however, until Luis Guillermo Solís was elected president in 2014, bringing his center-left Citizens' Action Party to power for the first time (MOLINA JIMÉNEZ, 2014). Solís's running mate, Ana Helena Chacón Echeverría, was a longtime supporter of IVF, the rights of sexual minorities, and the decriminalization of abortion. A week after taking office, the new president hoisted the rainbow flag of the LGBT pride movement over the presidential palace. The election was widely interpreted as a defeat for the old political elites and their conservative values, and a victory for a progressive human rights agenda, including sexual and reproductive rights. Breaking the congressional stalemate over IVF, however, would not prove easy.

In September 2015, amid perpetual legislative gridlock, Solís issued an executive decree lifting the IVF ban. The Sala IV immediately overruled him, stating that the ban could be rescinded only by the legislature. This was an obvious catch-22, since no IVF bill could ever pass in the legislature, given the evangelicals' ability to filibuster. Meanwhile, the General Assembly of the OAS was watching. It gave a diplomatic vote of confidence to Costa Rica in June 2015 when it elected Elizabeth Odio Benito - a Costa Rican "human

4 "Pura vida," meaning "pure life," is a Costa Rican salutation used mainly by young people and tourists to refer to the happy life one enjoys in Costa Rica. The addition of a question mark suggests that things are not quite as "pure" as the phrase implies. 
rights superstar" (BRYSK, 2005, p. 455), strong supporter of women's rights, former minister of justice, and first female judge on the International Criminal Court - to a seat on the Inter-American Court. The standoff between Solís and the Sala IV ended on February 26, 2016, when the Inter-American Court determined that the executive decree allowing IVF was indeed valid. The court gave the state a two-year grace period - until 2018 - to make IVF available through the national health system. In April 2020, the Costa Rican Social Security system announced the first IVF baby born through the public health system in twenty years (CHACÓN, 2020).

\section{2. INTERNATIONAL IMPLICATIONS}

It is difficult to overstate the continental implications of the Inter-American Court ruling in Artavia Murillo et al. ("In Vitro Fertilization") v. Costa Rica. Decisions made by the Inter-American Court are vinculante (binding) and inapelable (not subject to appeal) in the twenty-three countries that have ratified the American Convention (see LEMAITRE and SIEDER, 2017). Artavia Murillo v. Costa Rica should therefore have major repercussions for sexual and reproductive rights throughout the region, affecting policies related to assisted reproductive technologies, stem cell research and regenerative medicine, hormonal contraceptives, therapeutic abortion, adoption, surrogacy, and parenting. In addition to stating that the IVF ban violates the rights to privacy, liberty, personal integrity, and to form a family, the InterAmerican Court established for the first time in international law that reproductive rights are human rights, that embryos cannot be considered juridical "persons," and that the rights of embryos may not take precedence over those of women. The Inter-American Court also dealt a big blow to international pro-life activists by clarifying article 4.1 of the American Convention on Human Rights, stating that "conception" should be defined not as the fertilization of gametes but as the implantation of an embryo in a woman's womb. ${ }^{\mathbf{5}}$

Outside of Costa Rica, reproductive rights activists greeted the Inter-American Court ruling as a milestone for secular reproductive rights jurisprudence because it establishes the

5 The pro-life interpretation of article 4.1 is not consistent with the facts. In 1981, the Inter-American Commission held that "the right-to-life provisions provided by the American Convention on Human Rights and the American Declaration on the Rights and Duties of Man were compatible with a woman's right to access safe and legal abortions" (HUMAN RIGHTS WATCH, 2020, p. 19; emphasis added). The 2012 Inter-American Court ruling in Artavia Murillo v. Costa Rica clarified article 4.1 even further, stating that the right to life of embryos and fetuses is not absolute and that women's lives must take precedence over them. Conservatives are seeking a legal justification to reinstate a reading that supports a legal "right to life" under inter-American law. C-Fam puts its opposition bluntly: "The 5-1 decision, Murillo v. Costa Rica, stoked concern because the [American Convention on Human Rights] is the only treatly to explicitly protect the right to life "from the moment of conception"” (TOZZI, 2012). 
right to reproductive autonomy, the right to access reproductive health services, and the notion that embryos are best protected by protecting the rights of pregnant women. Some authors argued that it would also "prevent passage of so-called personhood initiatives in the U.S. and elsewhere" (CROCKIN, RIBAS and ESCALANTE, 2013, p. 330), even though the United States has not ratified the American Convention on Human Rights. Opponents of the ruling were (and continue to be) outraged. "Costa Rica was a pioneer state in protecting human life from its earliest stage of development," but the Inter-American Court's decision "has forced the country to regress in its recognition and protection of the unborn, namely, the human embryo" (DE JESÚS, OVIEDO ÁLVAREZ and TOZZI, 2013, p. 164; see also OSPINA DE FONSECA, 2013). Catholic bishops gathered in Guanajuato, Mexico (arguably the seat of conservative Catholicism in Latin America), in April 2013 to issue a formal condemnation. Legal analyses continue to proliferate today, with some opponents angrily questioning the very integrity of the inter-American human rights system and others determined to wrest control of the system (DE JESÚS, OVIEDO ÁLVAREZ and TOZZI 2013; LEAL, 2013; see also PANOTTO, 2020).

\section{I.3.Therapeutic Abortion}

In the years following the IVF dispute, Costa Rica faced another alleged violation of reproductive rights, this time over the issue of therapeutic abortion. Legal - that is, nonpunishable - abortion is permitted under article 121 of the Costa Rican Penal Code when the life or health of the pregnant woman is at risk. In practice, however, medical personnel rarely perform therapeutic abortion due to a lack of clear guidance about why, when, and how the procedure is legally allowed (CARRANZA, 2007; see also ARROYO NAVARETE, 2017; COLECTIVA POR EL DERECHO A DECIDIR, 2009; MARÍN MORA and MORALES MUÑOZ, 2017; SAGOT RODRÍGUEZ and CARCEDO CABAÑAS, 2002). Without clear guidance in the form of an official technical decree or protocol (norma técnica), therapeutic abortion was effectively banned.

Conservative religious activists oppose expanding the terms of nonpunitive therapeutic abortion. The penal codes of several Latin American countries allow nonpunishable abortion (aborto no punible) on certain grounds, such as to preserve the life or health of the pregnant woman, when the pregnancy results from rape or incest, and when the fetus suffers from a congenital anomaly incompatible with life (see CEPAL, n.d.). In the 1990s and beyond, reproductive rights advocates began working with inter-American human rights organizations to ensure that therapeutic abortion would be available to those who needed it (GONZÁLEZ VÉLEZ, ORTIZ-ORTEGA and RAMOS, 2008). ${ }^{6}$ Iconic cases were considered by

6 By 2020, prominent strategists argued that this model had failed. It allows abortion to remain criminalized, as Paola Bergallo points out, so that women who wish to obtain a nonpunishable abortion are forced 
the inter-American human rights bodies in Mexico in 1999 and in El Salvador in 2013 and 2019 (TARACENA, 2002; PEÑAS DEFAGO, 2018; CENTER FOR REPRODUCTIVE RIGHTS, 2019). Gradually, legislative reforms and judicial cases expanded the grounds on which pregnancy could be legally terminated in Argentina, Brazil, Chile, Colombia, El Salvador, and Mexico (CENTER FOR REPRODUCTIVE RIGHTS, 2017).

In 2008, a 26-year-old Costa Rican woman called "Ana" (a pseudonym; in legal documents she is referred to as A.N.) was denied a therapeutic abortion after doctors told her in the seventh week of pregnancy that her fetus suffered from a fatal developmental anomaly. Distressed at the prospect of carrying a nonviable pregnancy, Ana requested a therapeutic abortion. Doctors refused. Ana appealed to the Sala IV but was turned down on the grounds that her psychological distress was caused not by the fetus but by her own state of mind. Ana carried the pregnancy to term, but the baby was stillborn. A coalition of advocates filed a complaint on Ana's behalf with the Inter-American Commission on Human Rights, charging that she had been denied a health service to which she was legally entitled (CENTER FOR REPRODUCTIVE RIGHTS, n.d.).

Because the IVF case was still in progress at the time this happened, the Costa Rican government wanted to avoid a second high-profile investigation into its reproductive rights obligations. It therefore negotiated with the commission for a friendly resolution, according to which the state would develop guidance to allow nonpunishable therapeutic abortion. Indeed, guidance was drafted in 2009, but it quickly vanished into bureaucratic limbo. Nothing happened, but nor did the matter disappear. In 2012, another woman, "Aurora," aged 32, learned that the fetus she was carrying suffered from a rare congenital defect. Doctors said it would not survive. Aurora appealed to the Sala IV for permission to receive a therapeutic abortion but went into preterm labor while awaiting the decision; the baby was stillborn after an emergency cesarean (CENTER FOR REPRODUCTIVE RIGHTS, 2013). Advocates brought this case, too, to the Inter-American Commission. The government promised to resolve the matter by October 2015, but the deadline passed unmarked (VALVERDE, 2019; ARGUEDAS ORTIZ, 2015). Local advocacy groups stepped up their pressure. The Colectiva por el Derecho a Decidir asked:

What will the state say about its continuing failure to regulate the therapeutic interruption of pregnancy? How will it justify its lack of compliance, given that since 2009 the Costa Rican Social Security Institute has had a Guide to Procedures that it still hasn't approved?

to seek exceptions to the criminal standard. Reproductive rights advocates now argue that abortion should be removed entirely from penal codes (BERGALLO, 2018; see also GONZÁLEZ VÉLEZ, MELO ARÉVALO and MARTÍNEZ LONDOÑO, 2019). 
Will it continue to ignore cases such as those of Ana and Aurora? (COLECTIVA POR EL DERECHO A DECIDIR, n.d.)

In October 2017, the Inter-American Commission raised the temperature on Costa Rica with a press release urging "All States to Adopt Comprehensive, Immediate Measures to Respect and Protect Women's Sexual and Reproductive Rights" (INTER-AMERICAN COMMISSION ON HUMAN RIGHTS, 2017). It quoted the commission's special rapporteur on economic, social, cultural, and environmental rights, Soledad García Muñoz, as saying:

Denying access by women and girls to legal and safe abortion services or post-abortion care can cause prolonged and excessive physical and psychological suffering to many women, especially in cases involving risks to their health, unviability of the fetus, or pregnancies resulting from incest or rape. Without being able to effectively exercise their sexual and reproductive rights, women cannot realize their right to live free from violence and discrimination. (INTER-AMERICAN COMMISSION ON HUMAN RIGHTS, 2017)

The press release did not name any specific countries, but Costa Rica was implicated in the following exhortation:

The Inter-American Court also urges the States in the region that still lack an adequate regulatory framework to adopt legislation designed to ensure that women can effectively exercise their sexual and reproductive rights, with the understanding that denying the voluntary interruption of pregnancy in certain circumstances does constitute a violation of the fundamental rights of women, girls, and adolescents. (INTER-AMERICAN COMMISSION ON HUMAN RIGHTS, 2017)

In January 2018, the issue of therapeutic abortion was eclipsed when the Inter-American Court issued an advisory opinion (known as AO 24-17) that essentially legalized samesex marriage throughout the Americas. Again, Costa Rica found itself at the forefront of sexual and reproductive rights lawfare in the Americas, as the story made international news ("Inter-American Human Rights Court Backs Same-Sex Marriage", 2018). The news came just a month before the Costa Rican presidential elections, which allowed the evangelical candidate, Fabricio Alvarado, to make it a campaign issue. A moral panic over its implications propelled the evangelical candidate to an unlikely victory in the first electoral round. The progressive candidate, Carlos Alvarado Quesada, of the Citizens' Action Party, won the presidency over his evangelical rival in the second round, by a large margin. Still, evangelicals picked up an unprecedented number of legislative seats, spurred in part by the moral 
panic incited over the same-sex marriage ruling. These gains foreclosed any legislative path to regulating therapeutic abortion. The Citizens' Action Party signed a formal pact with the more conservative Social Christian Party that asserts, in part, that the national government "[w]ill not modify any law related to abortion, by any government action at the national or international level. Not expand in any way the provisions of Article 121 of the Penal Code, whether by interpretation, protocol or reform" (ALVARADO QUESADA and PIZA ROCAFORT, 2018). President Alvarado announced that he would sign the norma técnica regulating therapeutic abortion before the end of 2019, thus fulfilling the country's promise to the Inter-American Commission, but also that he would not engage in any further actions to expand its provisions or decriminalize abortion. As the deadline neared, pressure mounted for and against (MARÍN, 2019). Reproductive rights advocates reminded the Inter-American Commission that Costa Rica had been under scrutiny since 2008 and had not yet complied with its 2015 promise to resolve the matter. The government was well aware that if the case were referred to the Inter-American Court, it might end up with another landmark human rights decision, as had happened with IVF (LARA SALAS, 2018). Alvarado and his minister of health finally signed the norma técnica in December 2019, as an executive decree, with relatively little fanfare (PRESIDENTE DE LA REPÚBLICAY EL MINISTRO DE SALUD, 2019).

With that, the matter may have seemed resolved. But in January 2020, evangelical legislators filed a complaint with the Sala IV, charging that the norma técnica was unconstitutional because only the Legislative Assembly has the authority to pass such laws (CORRALES, 2020). This echoed an argument made a month earlier by the Episcopal Conference of Bishops: "We consider it urgent and necessary that the norma técnica be submitted for legislative approval, giving it the status of a law of the Republic, because in dealing with the regulation of human life it constitutes the basic right on which all public liberties are based" (BOSQUE, 2019). This case thus follows the same playbook as the IVF case: the Catholic hierarchy insists on legislation while fully knowing that evangelical legislators will block all legislative petitions, thus forcing the president to act by executive decree, and then complaining to the constitutional court that said executive decree is unconstitutional and that legislation is required. The Sala IV rejected this complaint (MADRIGAL, 2020).

By late 2020, reproductive rights advocates told me that they had not yet seen the norma técnica. No one knew whether the protocol would clarify the definition of "health" or include mental health as grounds for a therapeutic abortion (GONZÁLEZ VÉLEZ, 2012). No one knew whether young girls would qualify for therapeutic termination of pregnancy. ${ }^{7}$ No

$7 \quad$ The United Nations Population Fund (2016) estimates that approximately 500 babies are born each year to girls under the age of fifteen in Costa Rica. 
one knew whether there would be a gestational age limit, how therapeutic abortions would be performed, whether both medication and surgical abortion would be permitted, or whether hospital chiefs would be prevented from encouraging conscientious objections on the part of medical personnel, as has happened elsewhere (DE ZORDO and MISHTAL, 2011). Advocates wonder whether Costa Rica may end up where it was twenty years ago, without clear guidance to inform medical protocols for pregnancies that threaten women's health and lives. ${ }^{\mathbf{8}}$

To summarize, Costa Rica holds a storied position within the inter-American human rights system. Decisions made by its constitutional court are taken seriously by the transnational legal community. Pro-life and pro-family activists were therefore thrilled when the Sala IV issued a series of rulings banning IVF, same-sex marriage, and therapeutic abortion. The real problem, in their view, surfaced when the inter-American human rights system, including the Inter-American Court, disagreed with and overturned its rulings. Critics charged that the Inter-American Court used its power to create new rights (see YOSHIHARA and SYLVA, 2007). This meant that anyone who wanted to prevent the expansion of sexual and reproductive rights would have to tackle what they saw as obstacles within the inter-American human rights system.

\section{Attacking Human Rights-Based Approaches}

Pro-life and pro-family activists are now targeting the inter-American system of human rights by expanding and diversifying their transnational networks and coordinating with right-wing governments (cf. YAMIN, DATTA and ANDIÓN, 2018, p. 548; CAVALLARO et al., 2019; PANOTTO, 2020). "They are uniting to attack "rights-based approaches"

8 Meanwhile, religious activists are lobbying for a policy that would, in their words, "save both lives."This slogan was developed by activists in the global anti-abortion movement, where it is used to justify keeping restrictive and punitive abortion laws in place. It became more widespread in Ireland in 2012, when abortion opponents began to tout it as a response to calls for therapeutic abortion. Abortion is never medically justified, they say, because it is possible to save both the pregnant woman's and the fetus's lives (see MORGAN, 2017). Ever since then, the slogan has been used around the world, including in Latin America (especially Argentina, Chile, and El Salvador). In 2019, the bishop of Ciudad Quesada used the phrase in response to the signing of the norma técnica. He explained that medical authorities can "respect both lives" by performing necessary medical procedures, even if they cause the death of the fetus, as long as their intentions before God "are to not provoke the death of the baby" (VATICAN NEWS, 2019). Feminists argue that "save them both" is based on Catholic moral philosophy, which functions to mis-identify and delay legal therapeutic abortion. More ominously, the "save them both" philosophy can cost women's lives by delaying treatment in the case of medical emergencies.

9 For a list of the main religious conservative nongovernmental organizations that work at the United Nations, see Peñas Defago, Morán Faúndes, and Vaggione (2018, p. 20); Moragas (2020); Yamin, Datta, and Andión (2018). 
promoted by the UN and OAS (see MORAGAS, 2020; PANOTTO, 2020). They charge that multilateral organizations have hijacked human rights and created new rights, including abortion and marriage equality, thus undermining natural rights and natural law (DeLOACH, 2019). This effort was boosted under the administration of US President Donald J. Trump (2016-2020), who oversaw an aggressive public effort to "protect the precious gift of life at every stage, from conception until natural death" (GOVERNMENT OF THE UNITED STATES, 2020, p. 14). In what follows, I argue that the opposition to recent Inter-American Court rulings is motivated by the Inter-American Court decisions in Artavia Murillo v. Costa Rica and the same-sex marriage advisory opinion, along with related disputes over gender and sexuality, reproduction, and "religious liberty." The current offensive could have lasting repercussions for international human rights jurisprudence in the Americas.

\section{I. The Organization OF AMerican States}

Problems within the OAS are legendary, yet many believe that the organization offers the best hope for safeguarding human rights in the Americas (CONTESSE, 2019; COSOY, 2019; MARCETIC, 2019). Conservative activists, as Camila Gianella points out, are targeting the OAS as part of their larger Latin American "transnational anti-abortion social movement" (GIANELLA MALCA, 2018, p. 352). In actuality, the OAS takes no official position on abortion, but pro-life and pro-family groups have mobilized ever-larger contingents to attend its annual assembly of civil society organizations (PANOTTO, 2020, p. 103; EVANGELICAL FOCUS, 2020). In 2013, for example, conservative civil society organizations mobilized to pressure the OAS: "Organizations opposed to gender rights began to attend the General Assembly meetings of the OAS in a massive and coordinated fashion [...], with the goal of blocking the adoption of binding instruments and resolutions favorable to sexual and reproductive rights" (MORAGAS, 2020, p. 39). There, they lobby the OAS and, through it, the Inter-American Commission on Human Rights and the Inter-American Court, objecting to the language of "sexual and reproductive health" and to agreements that would ban discrimination against diverse families and sexual minorities (KANE, 2015).

Conservatives working in this movement reserve special antipathy toward the InterAmerican Court ruling in Artavia Murillo v. Costa Rica because, in their view, "activist judges" used the inter-American human rights system to provide a legal justification to decriminalize abortion. Their attempts to roll back the ruling take several forms. Some simply ignore the ruling entirely, pretending it does not exist and insisting on an originalist interpretation of the American Convention on Human Rights. Others issue nonbinding consensus declarations (such as 2013 Guanajuato Declaration on In Vitro Fertilization, mentioned above, or the 2020 Geneva Consensus Declaration), which serve to generate talking points and foster "transnational legitimacy" (YAMIN, DATTA and ANDIÓN, 2018, p. 567; MORGAN, 2019). Some put political pressure on officers of the OAS, forcing them to meet 
pro-life litmus tests ${ }^{10}$ and appoint pro-life commissioners and judges. By 2018, Human Life International could report that "the pro-life and pro-family civil society organizations have established a solid presence at the OAS" (YOSHIHARA, 2018). They are also recruiting an ever-larger network of transnational actors to bring pressure on the OAS.

Some of these strategies are coordinated by ADF International, an ultraconservative legal advocacy organization with evangelical roots (see KANE, 2015;YAMIN, DATTA, and ANDIÓN, 2018). ADF received accreditation from the OAS in 2014. When the United States cut US\$210,000 from the OAS budget in 2019, accusing the Inter-American Commission of lobbying to legalize abortion, ADF boasted that it "helped create language that resulted in the US government cutting taxpayer funding to OAS for promoting abortion" (ADF INTERNATIONAL, n.d.; MORELLO, 2019). ${ }^{11}$ ADF alleges that the OAS promotes abortion overseas, engages in pro-abortion "cultural imperialism," and intervenes "in the national sovereignty of Member States" (ADF INTERNATIONAL, 2019). Conservative parliamentarians and legislators across the Americas make similar allegations. In 2016, for example, two US Republican senators criticized the OAS for its pro-abortion "cultural imperialism" in Latin America and said that the Inter-American Court had "imposed" IVF on Costa Rica. They further asserted that the right to life should be a sovereign matter (CHRETIEN, 2016). In 2018, a group of US senators urged US Secretary of State Pompeo to cut off funding to the OAS, writing that "sovereignty is the inherent right of nations to live according to their own values. No right is more central to the self-determination of a nation than the right to life" (LANKFORD, TILLIS and ENZI, 2018).

Attacks against the OAS reached a new level in April 2019, when the government of Chile - joined by Argentina, Brazil, Colombia, and Paraguay - sent a statement to the Inter-American Commission on Human Rights asking for greater deference and judicial sovereignty. They called for the inter-American human rights system to respect national sovereignty, autonomy, and the decisions of national constitutional courts. Coming as it did from Latin American countries that had recently emerged from decades of military dictatorship, the statement sent "shock waves through the Latin American human rights community" (CONTESSE, 2019, p. 376). Human rights advocates were quick to defend the inter-American human rights system

In 2020, Luis Almagro, who was running for a second term as secretary general of the OAS, was persuaded by pro-life groups to state his support for the notion that the right to life is a fundamental right (ROBERTSON, 2020).

11 After the United States cut off funds to the OAS in 2019, it circulated a letter among UN member states asking them to "join the United States in ensuring that every sovereign state has the ability to determine the best way to protect the unborn and defend the family" (FORD, 2019). This gave the appearance of weaponizing US foreign assistance in the service of ADF International's pro-life and pro-family mission. 
(AMNESTY INTERNATIONAL, 2019), but the point had been made: conservatives could use pro-life, pro-family arguments to mount a coordinated, high-profile challenge to the interAmerican human rights system.

The call for national sovereignty is especially striking, because it implies that Inter-American Court decisions need not be considered binding. A 2020 report from the US Department of State to the UN Human Rights Council states it clearly: "The United States believes in the sovereign right of nations to make their own laws to protect the unborn, and rejects any interpretation of international human rights to require any State to provide access to abortion" (GOVERNMENT OFTHE UNITED STATES, 2020). Conservatives prefer "ordinary democratic politics and the legitimate exercise of national sovereignty" - such as referendums, legislation, and national courts where they hope to prevail - over what they call "rights claims that seek to bypass democratic institutions and processes" (US STATE DEPARTMENT, 2020). In other words, they do not want supranational human rights courts such as the Inter-American Court to have the final word. Because "there is no global Supreme Court," one law professor argues, a regional court (such as the Inter-American Court) does not "have the independent authority to compel compliance with their rulings" (COLLETT, 2019 , p. 249). Ligia Castaldi, an anti-abortion legal scholar at the Ave Maria School of Law, asserts that sexual and reproductive rights advocates exploit the courts to achieve rulings that never would have been possible through legislative means or plebiscite. "It's easier to obtain consensus among a small group of nine or seven judges," she says, than to convince the populace to "authorize the destruction of unborn children" ("Especialista analiza en libro leyes proaborto", 2020). The ultimate goal of these conservatives is to limit the scope and power of the inter-American human rights system and give states the final authority to determine life and family matters.

Such multipronged pressure on the OAS has resulted in several changes. There are now more Christian evangelicals and pro-life, pro-family civil society organizations at annual OAS gatherings than ever before (PANOTTO, 2020). In 2019, the Holy See won permanent observer status for its representative to the OAS (MORAGAS, 2019), and a Guatemalan prolife attorney was elected to the Inter-American Commission on Human Rights for a threeyear term (RAMOS, 2019). In 2020, OAS Secretary General Luis Almagro survived pro-life opposition to his re-election bid when he issued a statement that the right to life is "fundamental" and allowed the OAS General Assembly to declare October 27 as International Day of Religious Freedom (EVANGELICAL FOCUS, 2020). By 2020, the anti-abortion lobby had learned how to hold the OAS hostage to its demands.

\subsection{Pompeo's Commission on Unalienable Rights}

Another attack on rights-based approaches came in July 2019, when US Secretary of State Pompeo announced the creation of a Commission on Unalienable Rights, charged with providing "fresh thinking about human rights discourse where such discourse has departed from 
our nation's founding principles of natural law and natural rights" (US DEPARTMENT OF STATE, 2019). Some of the members of Pompeo's commission wanted to develop a framework that would allow all sovereign nations to interpret international human rights obligations as they pleased. If successful in the long term, this strategy could undermine the authority of supranational human rights courts. The commission was headed by Mary Ann Glendon, who has worked closely with another commission member, Notre Dame law professor Paolo Carozza, to make the case that Latin America has a special tradition of human rights based in social Catholicism. In a series of articles, Glendon and Carozza argued that Latin Americans' unique vision of human rights (including the right to life of embryos and fetuses) has yet to be fully realized (see MORGAN, 2014). It is no surprise, then, that the commission included several individuals known for their anti-abortion views. Its existence formed part of a transnational strategy to escalate attacks against an allegedly activist and ideological inter-American human rights system. The commission's final report, issued in August 2020, proposed a hierarchy of rights beginning with property rights and the right to religious liberty. It offered language that could bolster national sovereignty with respect to human life and human dignity, religious liberty, and heteronormative notions of family, marriage, pregnancy, and sexual morality, although it stopped short of condemning reproductive and sexual rights in strong terms.

The commission's report laid the groundwork to contest a concept known as conventionality control. This doctrine, created in 2006, holds that "all domestic judges must follow the Inter-American Court's interpretation of the American Convention" (CONTESSE, 2018). Under the doctrine of conventionality control, decisions by the Inter-American Court overrule those decided by domestic courts and are binding on all states that have ratified the American Convention. As upholder of the court's mandates, Costa Rica has always abided by the doctrine of conventionality control. It was thus disingenuous for US Senators Marco Rubio and Mike Lee to assert, as they did in 2016, that "[w]hatever one's views about IVF, there is no justification for an international entity to impose its views on this issue on Costa Rica" (CHRETIEN, 2016). Many conservative legal activists reject conventionality control, to greater or lesser degrees. One of the more extreme critiques is voiced by Stefano Gennarini of C-Fam, who lambasts the Inter-American Court for claiming that its decision is binding on other countries of the Americas "under a legal doctrine of 'constitutionality control.'” Gennarini continues, "The Court effectively saw itself as ordering all countries in Central and South America to allow homosexual marriage, transgender laws, and government sanctioned artificial reproduction as flowing from the nondiscrimination provision in the convention" (GENNARINI, 2020).

In what could be seen as a challenge to conventionality control, Pompeo's commission called for a "margin of appreciation" that would allow "[n]ation-states [to] have some leeway to base their human rights policy on their own distinctive national traditions" (US DEPARTMENT OF STATE, 2020, p. 55). ADF International made precisely this argument in 2012, in response to Artavia Murillo v. Costa Rica: 
the Court should grant Costa Rica a "margin of appreciation," whereby it may decide the best way to protect the life of a developing human being, and that the Court should not exceed its authority by intruding upon an area that is solely within the competence of Costa Rica. (In other words, the Court should not impose a supranational Roe v.Wadetype decision on a sovereign nation, while disregarding the explicit text of the governing document.) (ALLIANCE DEFENSE FUND, 2012b)

It is both tempting and plausible to read the commission's report as outlining the political philosophy that could redress Artavia Murillo v. Costa Rica. From its opening pages, the report elevates the concept of national sovereignty, stating that "the securing of unalienable rights begins with the independence and sovereignty that enable a people to determine its own course and take responsibility for its decisions" (US DEPARTMENT OF STATE, 2020, p. 2). Later, the report makes the case that states are "legally bound" to abide by "certain norms of international human rights law" only "when that consent emerges from the constitutionally prescribed process" (US DEPARTMENT OF STATE, 2020, p. 33). In other words, a state is not obligated to comply with international court mandates which it deems unconstitutional. This is an understated rendering of a sentiment expressed earlier by Carozza, a member of the commission, who wrote, "there must exist a significant space for each state's constitutional self-determination within the inter-American system, especially in those states with healthy democratic political institutions and a consolidated rule of law" (CAROZZA and GONZÁLEZ, 2017, p. 437). Carozza is known to be a critic of Artavia Murillo v. Costa Rica, which he described as, "by a considerable measure, the worst decision on the protection of embryonic human life ever issued [by] an international court" (quoted in MORGAN, 2019, p. 6). When he defended the idea of guarding "space for each state's constitutional self-determination within the inter-American system," Carozza effectively argued that Costa Rica is exceptional and that the decisions of its capable constitutional court should be above Inter-American Court scrutiny. He and his co-author went on to single out the Inter-American Court's IVF ruling: "the [Inter-American] Court does not always respect the spaces of local freedom that states must have in the local interpretation of human rights in legitimate, democratic, constitutional systems (the 2012 Artavia Murillo v. Costa Rica case providing a particularly egregious example)" (CAROZZA and GONZÁLEZ, 2017, p. 441). This is precisely the argument made in the amicus brief that ADF International and others filed with the Inter-American Court, which cites the "impeccability of the Costa Rican democratic system." This is one reason, ADF claims, that the "Inter-American Court should grant Costa Rica a margin of appreciation, so that this State may decide the best way of protecting the life of a developing human being" (ALLIANCE DEFENSE FUND, 2012a, p. 2). The Commission on Unalienable Rights' report took up this idea, writing that the United States: 
counsels considerable deference to the decisions of democratic majorities in other countries, recognizing that self-governance may lead them to set their own distinctive priorities. The US promotion of fundamental rights should always be sensitive to the outcomes of ordinary democratic politics and the legitimate exercise of national sovereignty, and wary of rights claims that seek to bypass democratic institutions and processes. (US DEPARTMENT OF STATE, 2020, p. 56)

By this logic, Costa Rica's Sala IV could set its own “distinctive priorities" about the beginnings of life and personhood (MORGAN, 2019). If the Inter-American Court had respected the Costa Rican court's decisions to ban IVF, same-sex marriage, and therapeutic abortion, the profile of Latin American sexual and reproductive rights would look quite different than it does today.

The Commission on Unalienable Rights' report drew virulent criticism from a vast swath of the human rights community, including myself (MORGAN, 2021), charging that it was written in bad faith and could not be separated from the "political agenda it serves." In our reading, the report offers language and strategies that could result in weakening the concept of universality in inter-American human rights, empowering nation-states to ignore international laws with which they disagree.

\section{CONCLUSION}

As a small democracy with a mighty reputation, Costa Rica sits at the symbolic center of inter-American sexual and reproductive rights lawfare due to its unique history and stature. Of course this landscape is complex, transnational, and ever-evolving, which means that no single country can capture the big picture (GIANELLA MALCA, 2018; PEÑAS DEFAGO, MORÁN FAÚNDES and VAGGIONE, 2018). Nevertheless, events related here demonstrate Costa Rica's prominent (and sometimes overlooked role) in inter-American lawfare. The Inter-American Court of Human Rights is located in the heart of San José, and the country enjoys a reputation as a beacon of human rights. When the Sala IV banned IVF, prohibited same-sex marriage, and prevented therapeutic abortion, pro-life conservatives hoped it would mark the beginning of a wave of similar policies. But petitioners appealed to the interAmerican human rights system, which repeatedly struck down the decisions of the constitutional court. Conservatives were dismayed by Inter-American Court rulings that dramatically expanded reproductive and sexual rights across the continent.

These actions have prompted a backlash on the part of transnational pro-life and profamily activists who hope to capitalize on Costa Rica's stellar human rights reputation as they pressure the OAS and work to reset inter-American human rights law. Prominent Costa Ricans have proven willing to help; in 2019, former Costa Rican President Miguel Ángel Rodríguez called for Costa Rica to lead a movement to enshrine fetal rights in the American 
Convention on Human Rights. Rodríguez, a devout Catholic and short-lived secretary general of the OAS, used the occasion of the twenty-year anniversary of the National Day of Life before Birth to invite Costa Rica to file a formal reservation to the American Convention on Human Rights, stating that the country would not abide by any decision that violates its defense of the unborn. He suggested that Costa Rica should propose an amendment to the convention that would declare the inviolability of human life from the moment of conception. He wants to prevent the Inter-American Court from "creating rights," in his words, without first obtaining consent from the member states (RODRÍGUEZ, 2019). As we follow the evolution of transnational pro-life and pro-family movements and strategies across Latin America, it will be important to keep an eye on what happens in Costa Rica.

\section{ACKNOWLEDGMENTS}

The author would like to thank Angélica Peñas Delfago, Soledad Díaz Pastén, María Carranza, and Gabriela Arguedas for their insights into events described here, although responsibility for the article's content is hers alone. All Spanish-language translations are her own.

\section{REFERENCES}

ACOSTA GAMBOA, Andrea. Bioética y derecho (fecundación in vitro). San José: Editorial Jurídica Continental, 2013.

ADF INTERNATIONAL. Historical Highlights. n.d. Available at: https://adfinternational.org/whowe-are/historical-highlights.

ADF INTERNATIONAL. US Government Cuts Taxpayer Funding to OAS for Promoting Abortion, Other Countries May Follow Suit. April 1 2019. https: / /adfinternational.org/news/us-government-cuts-taxpayer-fundingto-oas-for-promoting-abortion-other-countries-may-follow-suit.

ALLIANCE DEFENSE FUND. Brief of Amici Curiae. 2012a. Available at: http://www.adfmedia.org/ files/IVF-CostaRicaAmicus-English.pdf. 
ALLIANCE DEFENSE FUND. Murillo et al. v. Costa Rica: Protecting Life "from Conception" in the Inter-American System. 2012b. Available at: http://www.adfmedia.org/files/2012-05-08_Costa_ Rica_Update.pdf.

ALVARADO QUESADA, Carlos; PIZA ROCAFORT, Rodolfo E. Gobierno nacional: acuerdo por la esperanza, la equidad y el desarrollo. 2018. Available at: https://semanariouniversidad.com/wp-content/ uploads / 2018/03/Acuerdo-Gobierno-Nacional.pdf.

AMNESTY INTERNATIONAL. Inter-American System Is Crucial for Guaranteeing Human Rights in the Region. April 24 2019. Available at: https://www.amnesty.org/en/latest/news/2019/04/americassistema-interamericano-fundamental-para-derechos-humanos.

ARAYA, Jorge. Religión gana terreno en la política y se demora avance hacia un Estado laico. Semanario Universidad, June 1 2015. Available at: http://semanariouniversidad.ucr.cr/pais/religion-gana-terrenoen-la-politica-y-se-demora-avance-hacia-un-estado-laico.

ARGUEDAS ORTIZ, Diego. Costa Rican Women Try to Pull Legal Therapeutic Abortion Out of Limbo. IPS News, 24 June 2015. Available at: http:/ / www.ipsnews.net/2015/06/costa-rican-womentry-to-pull-legal-therapeutic-abortion-out-of-limbo.

ARGUEDAS RAMÍREZ, Gabriela. La violencia obstétrica: Propuesta conceptual a partir de la experiencia costarricense. Cuadernos Inter.c.a.mbio sobre Centroamérica y el Caribe, v. 11, n. 1, p. 155-180, 2014.

ARGUEDAS RAMÍREZ, Gabriela; MORGAN, Lynn M. The Reproductive Rights Counteroffensive in Mexico and Central America. Feminist Studies, v. 43, n. 2, p. 423-437, 2017.

ARROYO NAVARETTE, Larissa. Incest Case Attests That, in Costa Rica, Abortion Is Legal in Name Only. The Conversation, 11 April 2017. Available at: https://theconversation.com/incest-case-attests-that-incosta-rica-abortion-is-legal-in-name-only-75766.

BECKWITH, Francis J. Natural Law, Catholicism, and the Protestant Critique: Why We Are Really Not That Far Apart. Christian Bioethics: Non-Ecumenical Studies in Medical Morality, v. 25, n. 2, p. 154-168, 2019.

BERGALLO, Paola. Del fracaso del giro procedimental a la inviabilidad del modelo de causales. In: BERGALLO, Paola; SIERRA, Isabel Jaramillo; VAGGIONE, Juan (ed.). El aborto en América Latina: estrategias jurídicas para luchar por su legalización y enfrentar las resistencias conservadoras. Buenos Aires: Siglo XXI Editores, 2018. 
BOSQUE, Diego. Obispos piden que se discuta norma técnica para aborto terapeútico en Asamblea Legislativa. AmeliaRueda, December 17 2019. Available at: https://www.ameliarueda.com/nota/obispospiden-se-discuta-norma-tecnica-para-aborto-terapeutico-diputados.

BRYSK, Alison. Global Good Samaritans? Human Rights Foreign Policy in Costa Rica. Global Governance, v. 11, n. 4, p. 445-466, 2005.

CANCILLERÍA DE CHILE. Comunicado de Prensa Ministerior de Relaciones Exteriores - Ministerio de Justicia y Derechos Humanos sobre Sistema Interamericano de Derechos Humanos. April 11 2019. Available at: https: / / www.minjusticia.gob.cl/comunicado-de-prensa-ministerio-de-relaciones-exteriores-ministeriode-justicia-y-derechos-humanos-sobre-sistema-interamericano-de-derechos-humanos.

CARIBONI, Diana. Attack the OAS: Inside the Ultra-Conservative War on the Inter-American Human Rights System. Open Democracy, December 5 2019. Available at: https://www.opendemocracy.net/ en/5050/attack-oas-inside-ultra-conservative-war-inter-american-human-rights-system/.

CAROZZA, Paolo G.; GOnZÁLEZ, Pablo. The Final Word? Constitutional Dialogue and the InterAmerican Court of Human Rights: A Reply to Jorge Contesse. International Journal of Constitutional Law, v. 15, n. 2, p. 436-442, 2017.

CARRANZA, María. The Therapeutic Exception: Abortion, Sterilization and Medical Necessity in Costa Rica. Developing World Bioethics, v. 7, n. 2, p. 55-63, 2007.

CAVAllaro, James L. et al. Doctrine, Practice, and Advocacy in the Inter-American Human Rights System. Oxford: Oxford University Press, 2019.

CENTER FOR REPRODUCTIVE RIGHTS. A.N. v Costa Rica, n.d. Available at: https: / / reproductiverights. org/sites/default/files/documents/AN_v_Costa_Rica_Spanish.pdf.

CENTER FOR REPRODUCTIVE RIGHTS. Unspeakable Cruelty. September 6 2013. Available at: http:/ / www.reproductiverights.org/story/unspeakable-cruelty-in-costa-rica.

CENTER FOR REPRODUCTIVE RIGHTS. La Comisión Interamericana de Derechos Humanos hace un llamado para un mejor acceso a servicios de salud reproductiva. October 25 2017. Available at: https: / / reproductiverights. org/centro-de-prensa/la-comisi\%C3\%B3n-interamericana-de-derechos-humanos-hace-un-llamado-paraun-mejor-acceso

CENTER FOR REPRODUCTIVE RIGHTS. Inter-American Commission on Human Rights Files Case of Manuela vs. El Salvador before the Inter-American Court of Human Rights. October 10 2019. Available at: 
https:/ / www.reproductiverights.org/press-room/inter-american-commission-human-rights-filedcase-manuela-vs-el-salvador-inter-american.

CEPAL. Leyes sobre el aborto. n.d. Available at: https://oig.cepal.org/es/leyes/leyes-sobre-aborto.

CEPAL. Regional Review and Appraisal of Implementation of the Beijing Declaration and Platform for Action and the Outcome of the Twenty-Third Special Session of the General Assembly (2000) in Latin American and Caribbean Countries. Santiago: United Nations, 2015.

CHACÓN, Eysel. Nació la primera bebé fecundada por invitro en la CCSS. Costa Rica Medios, April 19 2020. Available at: https: / / costaricamedios.cr/2020/04/19/esta-noche-nacio-la-primera-bebe-fecundadapor-fiv-en-la-ccss/.

CHRETIEN, Claire. Senators Slam US-Funded OAS for Pro-Abort 'Cultural Imperialism' in South America. LifeSite News, October 5 2016. Available at: https://www.lifesitenews.com/news/us-senatorsdenounce-org.-of-american-states-anti-family-agenda-in-south-am.

COLECTIVA POR EL DERECHO A DECIDIR. CIDH interpela a Costa Rica por embarazo forzado: Casi expira plazo de respuesta. n.d. Available at: https://www.cddperu.org/informacion/noticias/cidhinterpela-costa-rica-por-embarazo-forzado-casi-expira-plazo-de-respuesta.

COLECTIVA POR EL DERECHO A DECIDIR. Interrupción terapéutica del embarazo: Aportes para la reflexión. San José: Asociación Colectiva por el Derecho a Decidir, 2009.

COLLETT, Teresa Stanton. Against Ideological Colonization: The Teaching of Humanae Vitae and a Humanely Adequate Global Ethic. In: NOTARE, Theresa (ed.). HumaneVitae, 50 Years Later. Washington, DC: Catholic University of America Press, 2019.

CONTESSE, Jorge. Contestation and Deference in the Inter-American Human Rights System. Law and Contemporary Problems, v. 79, p. 123-145, 2016.

CONTESSE, Jorge. The Inter-American Court of Human Rights' Advisory Opinion on Gender Identity and Same-Sex Marriage. ASIL (American Society of International Law) Insights, v. 22, n. 9, 2018.

CONTESSE, Jorge. Conservative Governments and Latin America's Human Rights Landscape. AJIL Unbound, v. 113, p. 375-379, 2019.

CORRALES, Melany. Sala IV estudiará acción contra norma técnica del aborto terapéutico. SINART Costa Rica Medios, April 21 2020. Available at: https://costaricamedios.cr/2020/04/21/sala-iv- 
estudiara-accion-contra-norma-tecnica-del-aborto-terapeutico/.

CORRÊA, Sonia; PARKER, Richard. Preface. In: MORAGAS, Mirta. Políticas antigénero en América Latina: El caso de la Organización de los Estados Americanos (OEA). Rio de Janeiro: Observatorio de Sexualidad y Política, 2020.

COSOY, Natalio. ¿Qué y quién está detrás de la avanzada para limitar el Sistema Interamericano de Derechos Humanos? France 24, June 26 2019. Available at: https: / / www.france24.com/es/20190625limites-sistema-interamericano-ddhh-oea.

CROCKIN, Susan L.; RIBAS, Delia; ESCALANTE, Gerardo. Costa Rica's Absolute Ban on In Vitro Fertilization Deemed a Human Rights Violation: Implications for U.S. Assisted Reproductive Technology Policy and 'Personhood' Initiatives. Fertility and Sterility, v. 100, n. 2, p. 330-333, 2013.

DE JESÚS, Ligia M.; OVIEDO ÁlVAREZ, Jorge;TOZZI, Piero A. El caso Artavia Murillo y otros vs. Costa Rica (fecundación in vitro): La redefinición del derecho a la vida desde la concepción, reconocido en la Convención Americana. Prudentia Iuris, v. 75, p. 135-164, 2013.

DELOACH, Andrew R. Saving Human Rights from the Human Rights Movement. Public Discourse: The Journal of the Witherspoon Institute, December 9, 2019.

DE ZORDO, Silvia; MISHTAL, Joanna. Physicians and Abortion: Provision, Political Participation and Conflicts on the Ground:The Cases of Brazil and Poland. Women's Health Issues, v. 21, n. 3, p. S32-S36, 2011.

DÍAZ, Luis Eduardo. Gobernación pide a Radio Fides sacar del aire campaña contra FIV. La Nación, June 28 2011. Available at: http://www.nacion.com/archivo/Gobernacion-Radio-Fides-campana-FIV_0_ 1204279706.html.

ESPECIALISTA analiza en libro leyes proaborto y Convención Americana de Derechos Humanos. ACI Prensa, June 7 2020. Available at: https: / / www.aciprensa.com/noticias/especialista-analiza-en-libroleyes-proaborto-y-convencion-americana-de-derechos-humanos-39596.

EVANGELICAL FOCUS. OAS General Assembly Calls Its Members to Protect Religious Freedom. Evangelical Focus, October 23 2020. Available at: https: / / evangelicalfocus.com/world/8657/oas-callsits-members-to-protect-religious-freedom.

FRANCE 24. ¿Quién quiere limitar el Sistema Interamericano de Derechos Humanos? RFI, June 272019. Available at: http: / /www.rfi.fr/es/americas/20190627-quien-quiere-limitar-el-sistema-interamericanode-derechos-humanos. 
FUENTES BELGRAVE, Laura. Politización evangélica en Costa Rica en torno a la agenda 'provida': ¿Obra y gracia del Espíritu Santo? Revista Rupturas, v. 9, n. 1, p. 82-103, 2019.

GENNARINI, Stefano. UN human rights boss congratulates Costa Rica on political upheaval over gay 'marriage'. LifeSite News, May 29 2020. Available at: https: / / www.lifesitenews.com/news/un-humanrights-boss-congratulates-costa-rica-on-political-upheaval-over-gay-marriage.

GIANELLA MALCA, Camila. Movimiento transnacional contra el derecho al aborto en América Latina. In: BERGALLO, Paola; SIERRA, Isabel Jaramillo; VAGGIONE, Juan (ed.). El aborto en América Latina: estrategias jurídicas para luchar por su legalización y enfrentar las resistencias conservadoras. Buenos Aires: Siglo XXI Editores, 2018.

GONZÁLEZ VÉLEZ, Ana Cristina. "The Health Exception”: A Means of Expanding Access to Legal Abortion. Reproductive Health Matters, v. 20, n. 40, p. 22-29, 2012.

GONZÁLEZ VÉLEZ, Ana Cristina; MELO ARÉVALO, Carolina; MARTíNEZ LONDOÑO, Juliana. Eliminating Abortion from Criminal Law in Colombia: A Just Cause. Health and Human Rights Journal, v. 21 , n. 2, p. $85-96,2019$.

GONZÁleZ VÉlEZ, Ana Cristina; ORTIZ-ORTEGA, Adriana; RAMOS, Silvina. Causal salud: interrupción legal del embarazo, ética y derechos humanos. 2008. CLACAI.

GOVERNMENT OF THE UNITED STATES. National Report Submitted in accordance with Paragraph 5 of the Annex to Human Rights Council Resolution 16/21. United Nations Human Rights Council. UN Doc. A/HRC/WG.6/36/USA/1, 2020.

HUMAN RIGHTS WATCH. International Human Rights Law and Abortion in Latin America. New York: Human Rights Watch, 2020.

INTER-AMERICAN COMMISSION ON HUMAN RIGHTS. Inter-American Court Urges All States to Adopt Comprehensive, Immediate Measures to Respect and Protect Women's Sexual and Reproductive Rights. October 23 2017. Available at: https://www.oas.org/en/iachr/media_center/PReleases/2017/165.asp.

INTER-AMERICAN COURT OF HUMAN RIGHTS. Case of Artavia Murillo et al. ("inVitro Fertilization") v. Costa Rica. 2012. Available at: http: / /www.corteidh.or.cr/docs/casos/articulos/seriec_257_ing.pdf.

INTER-AMERICAN Human Rights Court Backs Same-Sex Marriage. BBC News, January 102018. Available at: https://www.bbc.com/news/world-latin-america-42633891. 
KANE, Gillian. Latin America in the Crosshairs: Alliance Defending Freedom Takes Aim. Political Research Associates, July 13 2018. Available at: https: / / www.politicalresearch.org/2015/07/13/latinamerica-crosshairs.

KUKLA, Kevin. The Real Reason IVF Is Facing Possible Legalization in Costa Rica. Life Site News, November 28 2012. Available at: https://www.lifesitenews.com/opinion/the-real-reason-ivf-isfacing-possible-legalization-in-costa-rica.

LANKFORD, James; TILLIS, Thom; ENZI, Michael B. Letter to U.S. Secretary of State Mike Pompeo. December 21 2018. Available at: https: / / www.lankford.senate.gov/imo/media/doc/OAS\%20letter\% 20to\%20Sec\%20Pompeo.pdf.

LARA SALAS, Juan. Mujeres retoman en Comisión Interamericana de Derechos Humanos lucha por aborto terapéutico. La Nación, July 20 2018. Available at: https://www.nacion.com/el-pais/gobierno/ mujeres-retoman-en-comision-interamericana-de/MLJJFH3WPRH5FLW7ZWRDCK4L2E/story/.

LEAL, Alejandro. The Fall of the Inter-American Court of Human Rights. Truth and Charity Forum, March 25 2013. Available at: http: / / www.truthandcharityforum.org/the-fall-of-the-inter-american-courtof-human-rights/.

LEMAITRE, Julieta; SIEDER, Rachel. The Moderating Influence of International Courts on Social Movements: Evidence from the IVF Case against Costa Rica. Health and Human Rights Journal, v. 19, n. 1, p. 149-160, 2017.

LUNA, Florencia; WOLF, Allison B. Challenges for Assisted Reproduction and Secondary Infertility in Latin America. International Journal of Feminist Approaches to Bioethics, v. 7, n. 1, p. 3-27, 2014.

MADRIGAL, Luis Manuel. Sala IV rechaza recurso de diputados contra la norma técnica. Delfino, January 24 2020. Available at: https://delfino.cr/2020/01/sala-iv-rechaza-recurso-de-diputados-contra-lanorma-tecnica.

MARCETIC, Branko. How the Leader of the OAS Became a Right-Wing Hawk - and Paved the Way for Bolivia's Coup. In These Times, November 21 2019. Available at: https://inthesetimes.com/ article/ oas-bolivia-coup-venezuela-maduro-trump-luis-almagro.

MARÍN, Douglas. Aborto terapéutico genera polémica tras casi 50 años de legalizado en Costa Rica. Agencia EFE, September 26 2019. Available at: https: / / www.efe.com/efe/america/sociedad/abortoterapeutico-genera-polemica-tras-casi-50-anos-de-legalizado-en-costa-rica/20000013-4073420. 
MARÍN MORA, Alejandro Alfieri; MORALES MUÑOZ, Karla. La interrupción terapéutica del embarazo como derecho humano a la salud: Un análisis desde el bioderecho. Cadernos Ibero-Americanos de Direito Sanitário, v. 6, n. 1, p. 167-179, 2017.

MARINO, Katherine M. Feminism for the Americas: The Making of an International Human Rights Movement. Chapel Hill: University of North Carolina Press, 2019.

MOLINA JIMÉNEZ, Iván. Innovaciones electorales. La Nación, January 17 2014. http: / /www.nacion. com/opinion/foros/Innovaciones-electorales_0_1391060893.html.

MORAGAS, Mirta. La instalación de una oficina permanente del Vaticano en la OEA y las amenazas para los derechos sexuales y reproductivos. La Mala Fe, November 14 2019. https: / / www.lamalafe.lat/lainstalacion-de-una-oficina-permanente-del-vaticano-en-la-organizacion-de-estados-americanos-oea-y-las-a menazas-para-los-de-derechos-sexuales-y-reproductivos.

MORAGAS, Mirta. Políticas antigénero en América Latina: El caso de la Organización de los Estados Americanos (OEA). Rio de Janeiro: Observatorio de Sexualidad y Política, 2020.

MORELLO, Carol. Pompeo Cuts OAS Funds over Advocacy of Legal Abortion. Washington Post, March 262019.

MORGAN, Lynn M. Claiming Rosa Parks: Conservative Catholic Bids for "Rights" in Contemporary Latin America. Culture, Health and Sexuality, v. 19, n. 2, p. 1-15, 2014.

MORGAN, Lynn M. The Dublin Declaration on Maternal Health Care and Anti-Abortion Activism: Examples from Latin America. Health and Human Rights Journal, v. 19, n. 1, p. 41-53, 2017.

MORGAN, Lynn M. "Human Life Is Inviolable”: Costa Rica’s Human Rights Crucible. Medical Anthropology, v. 38, n. 6, p. 493-507, 2019.

MORGAN, Lynn M. Global Anti-Abortion Coalition Targets the Organization of American States. NACLA Report on the Americas, 2021. Available at: https://nacla.org/news/2021/06/04/global-antiabortion-coalition-targets-organization-american-states.

MURILLO, Alvaro. Costa Rica y la Corte Interamericana cumplen, entre presiones, 40 años de una relación estrecha. Semanario Universidad, July 172018.

NAVARRO DEL VALLE, Hermes. El derecho a la vida y la inconstitucionalidad de la fecundación in vitro. San José: Promesa, 2001. 
OSPINA DE FONSECA, Helena. Incongruencias del fallo de la CIDH. CoRis: Revista de Ciencias Sociales y Humanas, v. 9, p. 27-28, 2013.

PANOTTO, Nicolás. Incidencia religiosa en clave multilateral: La presencia de redes políticas evangélicas en las asambleas de la OEA. Cultura y Religión, v. 14, n. 1, p. 100-120, 2020.

PECHENY, Mario; FIGARI, Carlos; JONES, Daniel. Todo sexo es político: Estudios sobre sexualidades en Argentina. Buenos Aires: Libros del Zorzal, 2008.

PEÑAS DEFAGO, María Angélica. "Las 17”: Estrategias legales y políticas para legalizar el aborto en El Salvador. Revista de Bioética y Derecho, v. 43, n. 91-107, 2018.

PEÑAS DEFAGO, María Angélica; MORÁN FAÚNDES, José Manuel; VAGGIONE, Juan Marco. Conservadurismos religiosos en el escenario global: Amenazas y desafíos para los derechos LGBTI. New York: Global Philanthropy Project, 2018.

PRESIDENTE DE LA REPÚBLICA Y EL MINISTRO DE SALUD. Norma técnica para el procedimiento médico vinculado con el Artículo 121 del Código Penal: Decreto ejecutivo número 42113-S. 2019. Available at: https://www.ministeriodesalud.go.cr/sobre_ministerio/prensa/uci_decreto_ejecutivo_nt_ 42113_s.pdf.

PRIESTS FOR LIFE. Priests for Life Accredited by the Organization of American States. 2020. Available at: https://www.priestsforlife.org/international/oas.aspx.

RAMOS, David. ¿Qué significa que el nuevo miembro de la CIDH sea provida? ACI Prensa, July 22019. Available at: https: / / www.aciprensa.com/noticias / que-significa-que-el-nuevo-miembro-de-la-cidhsea-provida- 75907.

RIVERA JUARISTI, Francisco. The Amicus Curiae in the Inter-American Court of Human Rights (19822013). 2014. Available at: https://ssrn.com/abstract $=2488073$.

ROBERTSON, Geoffrey. The Case of the Pope: Vatican Accountability for Human Rights Abuse. London: Penguin Books, 2010.

ROBERTSON, Prudence. Pro-Life Leaders Commend OAS Secretary General Luis Almagro for Stating That Right to Life Is a Fundamental Right. Susan B. Anthony List, March 10 2020. Available at: https://www.sbalist.org/newsroom/press-releases/pro-life-leaders-commend-oas-secretary-general-luis-almagro-for-statin g-that-right-to-life-is-a-fundamental-right. 
RODRÍGUEZ, Miguel Angel. Vida antes de nacer. La República, August 5 2019. Available at: https: / / www.larepublica.net/noticia/vida-antes-de-nacer-2019-08-04-08-11-08.

SABATINI, Christopher. Why Congressional Republicans Should Support the Inter-American Commission on Human Rights. Global Americans, March 1 2019. Available at: https://theglobalamericans.org/2019/ 03/why-congressional-republicans-should-support-the-inter-american-commission-on-human-rights.

SAGOT RODRÍGUEZ, Montserrat; CABAÑAS, Ana Carcedo. Aborto inducido: Ética y derechos. Medicina Legal de Costa Rica, v. 19, n. 2, p. 63-77, 2002.

SALA CONSTITUCIONAL. Fecundación in vitro es inconstitucional. La Nación, October 122000. http: / / wvw.nacion.com/ln_ee/2000/octubre/12/sentencia.html.

SCALA, Jorge. Para recordar todos los días 10 de diciembre. La Mañana de Córdoba, November 23 2011. https: / / cnuvidayfamilia.wordpress.com/2011/11/25/para-recordar-todos-los-dias-10-dediciembre/.

TARACENA, Rosario. Social Actors and Discourse on Abortion in the Mexican Press: The Paulina Case. Reproductive Health Matters, v. 10, n. 19, p. 103-110, 2002.

TOZZI, Piero. The Inter-American Court versus the Rule of Law. C-Fam, December 27 2012. Available at: https://c-fam.org/friday_fax/the-inter-american-court-versus-the-rule-of-law/.

UNITED NATIONS POPULATION FUND. In Costa Rica, from Teen Mom to Girls' Rights Advocate. December 20 2016. Available at: https://www.unfpa.org/news/costa-rica-teen-mom-girls-rights-advocate.

US DEPARTMENT OF STATE. Department of State Commission on Unalienable Rights. Federal Register, May 30 2019. Available at: https:/ / www.federalregister.gov/documents / 2019/05/30/2019$11300 /$ department-of-state-commission-on-unalienable-rights.

US DEPARTMENT OF STATE. Report of the Commission on Unalienable Rights. Washington, DC: Department of State, 2020.

VAGGIONE, Juan Marco. (Re)acciones conservadoras. In: BERGALLO, Paola; SIERRA, Isabel Jaramillo; VAGGIONE, Juan (ed.). El aborto en América Latina: estrategias jurídicas para luchar por su legalización y enfrentar las resistencias conservadoras. Buenos Aires: Siglo XXI Editores, 2018.

VALVERDE, Rita. Mujer que acusó al Estado mantendrá demanda hasta que se aplique norma de aborto terapéutico. Semanario Universidad, December 12 2019. Available at: https: / / semanariouniversidad. 
com/ultima-hora/mujer-que-acuso-al-estado-mantendra-demanda-hasta-que-se-aplique-norma-deaborto-terapeutico/.

VATICAN NEWS. Costa Rica: Inaceptable cualquier camino que se quiera abrir para el aborto. Vatican News, December 12 2019. Available at: https: / / www. vaticannews.va/es/iglesia/news/2019-12/costarica-inaceptable-cualquier-portillo-quiera-abrir-aborto.html.

WORLD BANK. Fertility Rate, Costa Rica and Contraceptive Prevalence, Modern Methods, Costa Rica. 2020. Available at: https: / / data.worldbank.org/indicator/SP.DYN.TFRT.IN?locations=CR; https://data.worl dbank.org/indicator/SP.DYN.CONM.ZS?locations $=$ CR.

YAMIN, Alicia Ely; DATTA, Neil; ANDIÓN, Ximena. Behind the Drama: The Roles of Transnational Actors in Legal Mobilization over Sexual and Reproductive Rights. Georgetown Journal of Gender and the Law, v. 19, n. 3, p. 533-570, 2018.

YOSHIHARA, Susan. Abortion Activists Lose at Organization of American States. C-Fam, June 142018. Available at: https: / / c-fam.org/friday_fax/abortion-gay-activists-lose-organization-american-states/.

YOSHIHARA, Susan; SYLVA, Douglas A. Rights by Stealth: The Role of UN Human Rights Treaty Bodies in the Campaign for an International Right to Abortion. New York: International Organizations Research Group of the Catholic Family and Human Rights Institute, 2007.

ZAMORA CASTEllanOS, Fernando. Defensa constitucional de la vida en Costa Rica. Derecho en Sociedad, v. 4, p. 125-151, 2013.

\section{HOW TO QUOTE THIS ARTICLE:}

MORGAN, Lynn M. Costa Rica's Oversized Role in Latin American Sexual and Reproductive Rights Lawfare. Revista Direito GV, São Paulo, v. 17, n. 3, set./dez. 2021, e2137. https://doi.org/10.1590/23176172202137
Lynn M. Morgan

Professor Emerita of Anthropology, Mount Holyoke College, South Hadley, Massachusetts. Immorganamtholyoke.edu 